\title{
IMPLEMENTASI KEARIFAN BUDAYA LOKAL PADA MASYARAKAT ADAT KAMPUNG KUTA SEBAGAI SUMBER PEMBELAJARAN IPS
}

\author{
Agus Efendi \\ SMP Negeri 1 Tambaksari, Kabupaten Ciamis \\ Email: efenx@yahoo.co.id
}

\begin{abstract}
This article aims to provide an overview of the implementation of local wisdom in the indigenous community of Kampung Kuta as a source of social studies learning. The method used is ethnography and Classroom Action Research. The research showed that environmental wisdom as one of the growing cultural values in society are able to make Kuta remain sustainable natural environment. The values of local wisdom, particularly environmental wisdom, is very important to make learning more meaningful social studies. The significance of the values of local wisdom of Kuta indigenous peoples as a source of learning social studies is seen from the results of studies showing the presence of two important things. First, the interest and passion of learners have increased. Second, teachers and the book are no longer the only source of learning.
\end{abstract}

Keywords: wisdom local culture, indigenous peoples, learning resources

\begin{abstract}
Abstrak
Artikel ini bertujuan untuk memberikan gambaran tentang implementasi kearifan budaya lokal pada masyarakat adat Kampung Kuta sebagai sumber pembelajaran IPS. Metode yang digunakan adalah etnografi dan Penelitian Tindakan Kelas (PTK). Hasil penelitian menunjukkan, kearifan lingkungan sebagai salah satu nilai budaya yang berkembang dalam masyarakat mampu menjadikan lingkungan alam Kuta tetap lestari. Nilai-nilai kearifan budaya lokal, khususnya kearifan lingkungan, sangat penting untuk menjadikan pembelajaran IPS semakin bermakna. Arti penting nilai-nilai kearifan lokal masyarakat adat Kuta sebagai sumber pembelajaran IPS telihat pada dua hal penting. Pertama, minat dan gairah belajar peserta didik mengalami peningkatan. Kedua, guru dan buku tidak lagi sebagai sumber pembelajaran utama.
\end{abstract}

Kata kunci: kearifan budaya lokal, masyarakat adat, sumber pembelajaran

\section{A. Pendahuluan}

Indonesia merupakan bangsa yang memiliki keanekaragaman dalam berbagai hal. Salah satunya adalah budaya yang berkembang dalam masyarakat adat sebagai kekayaan nasional. Masyarakat adat secara tradisi terus berpegang pada nilai-nilai lokal yang diyakini kebenarannya dan menjadi pegangan hidup yang diwariskan secara turun temurun.

Sebagai kesatuan hidup, masyarakat adat memiliki nilai sosial-budaya yang layak dikembangkan dalam pembelajaran, seperti kesetiakawanan sosial (solidaritas) dalam melakukan aktivitas hidupnya. Selain memiliki kesetiakawanan sosial yang tinggi, masyarakat adat juga memiliki budaya luhur lain yang berupa gotong-royong, musyawarah, dan kerukunan. Perilaku prososial (prosocial behavior) tersebut masih melekat kuat dibandingkan dengan masyarakat yang memiliki tingkat heterogenitas yang lebih tinggi.

Berkenaan dengan lingkungan, nilai luhur yang dapat dikaji dari masyarakat adat adalah kearifan lokal dalam melakukan pengelolaan lingkungan. Sebuah nilai penting yang dimiliki masyarakat adat dalam berhubungannya dengan eksplorasi dan eksploitasi alam. Nilai budaya tersebutlah yang kemudian diyakini sebagai cara paling ampuh dalam mengelola alam. Salah satu bentuk kearifan lingkungan yang ditunjukkan masyarakat adat adalah dengan menjadikan hutan sebagai tempat yang dikeramatkan. Hutan 
dijaga dengan berbagai tabu yang berfungsi sebagai pengendali segala aktivitas manusia yang berhubungan dengan tempat tersebut. Ketaatan pada tabu yang diwariskan secara turun-temurun menjadikan hutan tetap lestari.

Terlepas dari unsur mistis yang ada di dalamnya, pemahaman tentang nilai-nilai budaya lokal penting dimiliki peserta didik, kini dan pada masa yang akan datang. Oleh karena itu, nilai-nilai budaya masyarakat tradisional yang dikembangkan dalam konteks kekinian, penting untuk dijadikan kajian dalam pembelajaran IPS sehingga terinternalisasi pada diri peserta didik. Tentu setelah dikaji secara ilmiah, mengapa nilainilai tersebut harus diwariskan pada mereka.

Nilai-nilai budaya local yang mulai terabaikan dalam kehidupan dewasa ini adalah sebuah isu penting dalam pembelajaran IPS. Hal ini merupakan usaha mencari solusi alternatif guna menyikapi dampak globalisasi yang makin mengkhawatirkan. Menghadapi globalisasi dengan segala dampaknya diperlukan berbagai pendekatan dengan mengerahkan semua potensi yang dimiliki sebuah bangsa, termasuk kearifan lokal suatu masyarakat adat. Sistem budaya lokal merupakan modal sosial (social capital) yang besar, telah tumbuh dan berkembang secara turun-temurun yang hingga kini kuat berurat-berakar di masyarakat. ${ }^{1}$ Oleh karena itu, penting untuk melembagakan kembali (reinstitusionalisasi) kearifan lokal, mengingat peranannya dalam membantu penyelamatan lingkungan. ${ }^{2}$ Lingkungan hidup memang sedang mengalami degradasi sebagai dampak negatif dari lompatan petumbuhan jumlah penduduk yang tidak terkendali serta globalisasi.

Globalisasi juga telah menimbulkan efek samping berupa pengikisan nilai-nilai luhur budaya bangsa, digantikan dengan budaya asing yang seringkali bertentangan dengan budaya yang dianut oleh peserta didik. Hal ini merupakan bentuk ketidakmampuan individu masyarakat dalam menghadapi dinamika sosialbudaya melalui proses belajar dari budaya asing, baik akulturasi maupun asimilasi. Dalam konteks global, fenomena tersebut seolah merupakan tumbal sebuah zaman. Bagi Indonesia,

\footnotetext{
1 Hikmat, Harry. 2010. Strategi Pemberdayaan Masyarakat. Bandung: Humaniora Utama Press. h. 169.

2 Susilo, D. Rahmat K. 2009 Sosiologi Lingkungan. Jakarta: Rajawali Press. h. 161.
}

masuknya nilai-nilai Barat yang menumpang arus globalisasi merupakan ancaman bagi budaya asli yang mencitrakan lokalitas khas daerah-daerah di negeri ini. ${ }^{3}$ Oleh karena itu, kerarifan lokal merupakan hal penting yang harus diwariskan kepada peserta didik sebagai generasi penerus bangsa.

Kearifan lokal merupakan kemampuan penyerapan kebudayaan asing yang datang secara selektif, artinya disesuaikan dengan suasana dan kondisi setempat. ${ }^{4}$ Kemampuan tersebut sangat relevan dengan tujuan pembelajaran IPS, terutama karena peserta didik dapat memilih dan memilah budaya mana yang sesuai dengan karakteristik budayanya.

Peserta didik sebagai generasi penerus yang hidup dalam waktu lain dengan problematika yang berbeda, tentu tidak akan begitu saja menerima warisan itu. Mereka akan melakukan pemilihan atau pengolahan kembali nilainilai yang diwariskan dan mengambil yang menurutnya paling cocok serta sesuai dengan kepentingan keselamatan dan kesejahteraan generasi berikut. ${ }^{5}$ Seleksi tersebut akan terjadi dengan baik melalui pembelajaran dengan menggunakan sumber belajar yang bermakna.

Berhubungan dengan lingkungan tempat tumbuh dan berkembangnya nilai-nilai budaya, peserta didik tinggal dalam masyarakat dan karena itu peserta didik perlu mengenal kehidupan masyarakat. ${ }^{6}$ Salah satu hal yang dihadapi oleh anggota masyarakat adalah isuisu sosial. ${ }^{7}$ Berbagai permasalahan sosial tidak terlepas dari fenomena alam atau lingkungan fisik di mana warga masyarakat tersebut tinggal. Pengajaran IPS yang melupakan masyarakat sebagai sumber dan objeknya, merupakan suatu bidang pengetahuan yang tidak berpijak kepada kenyataan. ${ }^{8}$ Sebagai contoh aplikatif, isu tentang global warming dapat dikaji dari dimensi lokal yang berupa nilai budaya yang telah terbukti mampu menjaga kelestarian hutan. Kemudian dikembangkan dalam dimensi global berupa

\footnotetext{
143.

3 Alma, Buchari. 2010. Pembelajaran Studi Sosial. Bandung: Alfabeta. h.

4 Atmodjo, M.M.S.K. 1986.” Pengertian Kearifan Lokal dan Relevansinya dalam Modernisasi" dalam Ayatrohaedi penyunting. Kepribadian Budaya Bangsa (Local Genius). Jakarta: Dunia Pustaka Jaya. h. 37.

5 Saini. K. M. 2004. Krisis Kebudayaan (Pilihan 10 essai). Bandung: Kelir. h. 27-28.

6 Wahab, Abdul Azis. 2008. Metode dan Model-Model Mengajar Ilmu Pengetabuan Sosial. Bandung: Alfabeta. h. 137.

$7 \quad$ Ibid, 137

8 Sumaatmadja, Nursid. 1984. Metodologi Pengajaran Ilmu Pengetabuan Sosial. Bandung: Alumni. h. 18.
} 
usaha pencegahan pemanasan suhu bumi. Pembelajaran ini mencoba melahirkan peserta didik yang memiliki kemampuan untuk berpikir secara global dan bertindak secara lokal (think globally, act locally). ${ }^{9}$

Pentingnya implementasi nilai-nilai budaya lokal dalam pembelajaran IPS dapat dikaji dari filsafat pendidikan yang mendasarinya, yaitu Perenialisme. Perenialisme memandang pendidikan sebagai proses penting dalam pewarisan nilai budaya. Nilai-nilai budaya yang dimiliki oleh masyarakat harus ditransformasikan dalam pendidikan, sehingga diketahui, diterima, dan dapat dihayati oleh peserta didik. Perenialisme memandang bahwa nilai yang lahir pada masa lalu adalah hal berharga untuk diwariskan kepada generasi muda.

Dalam pendidikan IPS, transformasi budaya bukan berarti melakukan indoktrinasi nilainilai yang terkandung di dalamnya, melainkan mengkaji secara logis, kritis, dan analitis sehingga peserta didik mampu memecahkan masalah yang dihadapinya secara nyata. Pendidikan IPS tidak dapat menafikan nilai-nilai yang berkembang pada masa lalu. Pendidikan IPS juga tidak dapat mengabaikan masa yang akan datang. Dengan demikian, pendidikan IPS harus mengakomodir segala kebutuhan peserta didik, baik pewarisan nilai budaya, pengembangan intelektual, serta mempersiapkan diri peserta didik untuk masa depan yang lebih baik.

Untuk mengkaji perkembangan nilainilai budaya masyarakat Kampung Adat Kuta, khususnya kearifan lingkungan, peneliti menggunakan metode etnografi. Selanjutnya, nilai-nilai budaya yang telah teridentifikasi akan diseleksi dan dipilih guna diimplementasikan sebagai sumber pembelajaran IPS di SMP Negeri 1 Tambaksari melalui Penelitian Tindakan Kelas (PTK).

\section{B. Kearifan Budaya Lokal Masyarakat Kampung Kuta}

Budaya yang berkembang dalam masyarakat Kuta sangat dipengaruhi oleh keadaan alam yang dihuni oleh masyarakat sebagai penghasil kebudayaan. Hal ini sesuai dengan teori ekologi budaya yang dikemukan oleh Steward bahwa

9 Naisbitt, J. 1994. Golbal Paradox (penterjeman: Budijanto). Jakarta: Binarupa Aksara. h. 81 . lingkungan dan budaya tidak dapat dilihat secara terpisah, tetapi merupakan produk campuran (mixed product) yang berproses lewat dialektika. ${ }^{10}$ Dengan demikian, budaya mencintai lingkungan yang berkembang dalam masyarakat Kuta juga dipengaruhi oleh keadaan alam tersebut. Salah satu bentuknya, tergambar dari prinsip masyarakat dalam memperlakukan hutan, yaitu "Leuweung Ruksak, Cai Beak, Manusa Balangsak" (Hutan rusak, air habis, manusia sengsara). Prinsip ini mengandung makna yang sangat dalam tentang arti hutan bagi kehidupan manusia. Terdapat beberapa tabu dalam masyarakat Kuta yang memiliki makna untuk pelestarian hutan, yaitu: tabu menggangu satwa, tabu membawa sebatang ranting pun, tabu meludah dan buang air besar/kecil, tabu membawa api, dan tabu menggunakan alat dari besi ketika membersihkan hutan.

Dalam konteks pembelajaran, kearifan budaya masyarakat Kuta dalam menjaga kelestarian lingkungan merupakan sumber belajar IPS penting di tengah lingkungan yang semakin mengalami kemunduran kualitas. Prinsip keseimbangan dan keberlanjutan dalam mengolah alam merupakan nilai penting yang harus diwariskan kepada peserta didik. Nilai tersebut lahir dari alam pikiran manusia sebagai anggota masyarakat sebagai pedoman dalam melangsungkan aktivitas sehari-hari.

Banyak nilai yang terkandung dalam sistem budaya yang berkembang dalam masyarakat Kuta. Meskipun dalam berbagai hal berbau mistis tetapi bila dikaji secara logis dan kritis, di dalamnya terkandung makna dan nilai yang penting dalam membangun hubungan harmonis antarmanusia dan antara manusia dengan alam. Keberadaan tabu ini memiliki nilai tersendiri bagi peserta didik yang dapat menunjukkan bahwa masyarakat sesederhana apapun tetap memiliki kecerdasan dalam menghadapi hidup.

Dalam masyarakat Kuta, di samping nilai kearifan lingkungan, masih banyak nilai budaya yang dapat diangkat sebagai sumber pembelajaran IPS. Namun demikian, tidak semua budaya yang berkembang dalam masyarakat Kuta memiliki nilai yang pantas diwariskan kepada peserta didik. Sebagai masyarakat adat,

10 Susilo, D. Rahmat K. 2009. Sosiologi Lingkungan. Jakarta: Rajawali Press. h. 81. 
di dalam masyarakat Kuta, selain berkembang kecerdasan lokal juga hidup "kejahatan lokal", sehingga tidak layak dijadikan sumber belajar IPS.

Dari hasil kajian, nilai yang patut diwariskan kepada peserta didik terdiri dari keteladanan, keberanian, interaksi sosial dan personal, tanggung jawab, rela berkorban, solidaritas, kerjasama, gotong-royong, kebersamaan, sopan, kemandirian, kesederhanaan, produktivitas, efisiensi, persamaan (equality) di depan hukum, keberlanjutan dan keseimbangan lingkungan. Nilai-nilai tersebut tercermin dari sikap dan perilaku masyarakat Kuta mulai dari awal pembentukan yang tergambar dari mitos hingga sekarang ini serta berbagai tabu dan sistem pengetahuan lokal yang berkembang.

Adapun tradisi masyarakat Kuta yang tidak layak diwariskan kepada peserta didik adalah sebagai berikut. Pertama, budaya yang masih mendeskreditkan perempuan yang tercermin dari tabu anak perawan berlama-lama di jamban, tabu ke jamban menjelang maghrib, tabu perempuan memakai sinjang jangkung. Kedua, ada persepsi yang tidak sesuai dengan ilmu pengetahuan umum, yaitu tabu menikah dengan mantan istri kakak atau adik. Ketiga, adanya tabu pergi ke jamban pada waktu zhuhur dan menjelang maghrib yang bertolak belakang dengan keharusan mengambil wudhu ketika waktu sholat tiba. Keempat, tabu menjadi pegawai negeri sipil sebab dapat menjadi penghalang terjadinya perubahan budaya.

\section{Kearifan Budaya Lokal Masyarakat Adat Kampung Kuta sebagai Sumber Pembelajaran IPS}

Pembelajaran IPS baru sebatas mengembangkan kemampuan menghafal, belum mengambangkan kemampuan berpikir. Kendatipun penting, guru tidak boleh terjebak hanya pada pengembangan kompetensi ini. Peserta didik tidak cukup dibekali dengan kemampuan menghafal untuk menghadapi kehidupan nyata sebab seringkali apa yang mereka pelajari di dalam kelas sangat berbeda dengan kenyataan di lapangan. Pada siklus pertama dan kedua, guru masih berkutat pada pengembangan konsep tekstual dengan melontarkan pertanyaan-pertanyaan mengenai definisi dan belum menghubungkan materi yang bersifat tekstual dengan isu-isu yang bersifat kontekstual. Peserta didik tidak diberikan kesempatan untuk mengembangkan kemampuan berpikir logis, kritis, dan memecahkan masalah.

Selain itu, pembelajaran IPS kurang ditunjang dengan pengembangan dan pemanfaatan media pembelajaran. Guru lebih fokus pada penggunaan buku dan LKS sebagai sumber pembelajaran. Media yang digunakan terbatas pada penggunaan peta atau atlas. Terbatasnya media pembelajaran, di samping karena kemampuan sekolah yang terbatas, juga disebabkan oleh keengganan guru membuat alat bantu tersebut. Selain itu, guru masih belum mampu menjadikan produk inovasi teknologi sebagai alat bantu pembelajaran. Guru hanya menggunakan papan tulis sebagai media yang digunakan untuk menyampaikan pesan pembelajaran. Hal itu terlihat pada tahap orientasi penelitian tindakan, bahkan hingga siklus pertama.

Selanjutnya, materi pembelajaran IPS kurang menyentuh aspek nilai dan keterampilan sosial padahal subjek kajian IPS manusia dan masyarakat, sehingga materi pembelajaran IPS harus sarat dengan nilai-nilai dan keterampilan sosial sebagai bekal kehidupan di tengah masyarakat. Tetapi karena terpaku pada penyampaian materi secara tekstual, maka nilainilai sosial yang ada dalam masyarakat menjadi terabaikan. Selain itu, karena aspek yang dikembangkan adalah kemampuan menghafal maka aspek keterampilan sosial menjadi termarginalkan, bahkan tidak tersentuh sama sekali.

Selain berkenaan dengan sumber pembelajaran, guru IPS juga masih terpaku pada metode ceramah. Metode ceramah menjadi salah satu metode yang paling banyak digunakan oleh guru untuk menyampaikan informasi. Walau penggunaan metode ini tetap penting tetapi tidak benar kalau metode ini digunakan untuk setiap pembelajaran. Setiap metode memiliki keunggulan dan kelemahan, termasuk dalam hal ini metode ceramah. Dengan terpaku pada metode tersebut menyebabkan sumber belajar lain terabaikan, termasuk sumber belajar yang terdapat dalam masyarakat berupa nilai- 
nilai sosial budaya yang sangat penting bagi peserta didik. Untuk itu diperlukan model yang menjadikan masyarakat sebagai laboratorium pembelajaran. Dengan menjadikan masyarakat adat Kuta sebagai laboratorium pembelajaran, peserta didik mendapatkan pengalaman nyata yang bermakna bagi dirinya.

Dari hasil PTK terlihat bahwa implementasi nilai kearifan budaya lokal pada masyarakat adat Kuta sebagai sumber pembelajaran IPS ternyata memiliki manfaat yang sangat besar dalam meningkatkan kualitas pembelajaran IPS. Salah satu indikatornya adalah tumbuhnya motivasi belajar peserta didik. Hal ini membuat atmosfir pembelajaran menjadi kondusif untuk mencapai tujuan pembelajaran, yaitu menciptakan manusia yang memiliki kearifan lingkungan.

Peningkatan motivasi peserta didik dapat mengubah anggapan buruk terhadap pembelajaran IPS sebagai pembelajaran yang membosankan dan tidak bermakna. Peserta didik tidak akan lagi menganggap IPS sebagai mata pelajaran kelas dua yang selama ini disematkan. Kecintaan peserta didik pada pembelajaran IPS akan berdampak pada kesiapan mereka untuk mengarungi kehidupan nyata dengan mendekatkan peserta didik pada nilai budaya bangsanya.

Implementasi kearifan budaya lokal pada masyarakat adat Kuta sebagai sumber pembelajaran IPS merupakan hal baru dalam pembelajaran IPS, khususnya di SMP Negeri 1 Tambaksari. Sebagai produk inovasi, pada tahap implementasi tentu menghadapi hambatan dalam berbagai aspek. Pertama, aspek kurikulum. Diberlakukannya KTSP merupakan lompatan kebijakan untuk mendongkrak kualitas pendidikan baik proses maupun hasil. KTSP memiliki kelebihan yang harus disikapi dengan bijak oleh pengembang dan implementor kurikulum agar dapat bermanfaat bagi penyelenggaraan pendidikan di setiap satuan pendidikan. Di dalam KTSP terdapat beberapa aspek inovasi, salah satunya berhubungan dengan pentingnya muatan lokal berupa nilainilai budaya sebagai sumber pembelajaran IPS di mana kurikulum yang dikembangkan oleh guru harus memasukkan unsur lokal serta sesuai dengan kebutuhan dan tuntutan setempat. Namun peluang tersebut belum dipahami dengan baik oleh guru. Guru belum terbiasa diberikan peluang untuk mengembangkan kurikulum sendiri melainkan disuapi dengan program instan yang tinggal menjalankannya.

Hambatan lainnya terjadi karena kemampuan guru dalam memahami landasan filosofis dalam pengembangan KTSP. Bila dilihat dari landasan filofis, pengembangan KTSP didasarkan pada filsafat rekonstruksionisme karena dapat mengakomodir berbagai aliran filsafat pendidikan termasuk perenialisme yang menghendaki pewarisan nilai budaya. Oleh karena itu, dalam kurikulum yang dikembangkan seharusnya dimasukkan nilai-nilai budaya lokal untuk diwariskan kepada peserta didik.

Pemahaman hal tersebut masih mengalami distorsi di lapangan. Muatan lokal yang diamanatkan KTSP sering direduksi dengan cara membentuk mata pelajaran tertentu yang bernuansa kedaerahan seperti Mulok Bahasa Sunda. Guru belum menjadikan pelajaran IPS sebagai mata pelajaran yang memiliki potensi untuk mewariskan nilai-nilai lokalitas budaya sebuah masyarakat.

Masalah lainnya, IPS adalah mata pelajaran yang harus disajikan secara terpadu tetapi dalam implementasinya masih terjadi kesalahan dengan menyajikan IPS secara terpisah-pisah. Pembelajaran IPS di SMP Negeri 1 Tambaksari, khususnya yang dilakukan mitra peneliti dibagi dan disajikan berdasarkan disiplin ilmu sosial secara terpisah, sehingga tidak mencerminkan sebagai sebuah kajian yang memiliki keterkaitan. Pada akhinya, pendidikan IPS tidak mampu menyiapkan peserta didik untuk menghadapi kehidupan secara interdisipliner dan multidisipliner.

Kedua, Aspek Guru. Selain berhubungan langsung dengan kurikulum, terdapat masalah lain yang masih terjadi pada guru IPS di lapangan, antara lain sebagai berikut.

1. Guru masih menempatkan peserta didik hanya sebagai penerima pesan. Guru belum memahami bahwa interaksi pembelajaran harus berlangsung dua arah atau bahkan multiarah, sehingga interaksi antara peserta didik dengan sumber belajar terjalin dengan baik. Model pembelajaran yang dikembangkan guru masih menempatkan sosok guru sebagai 
sumber pembelajaran terpenting (teacher centered).

2. Guru belum memanfaatkan lingkungan dengan nilai budayanya sebagai sumber pembelajaran walaupun tahu nilai tersebut sangat bermanfaat bagi peserta didik. Orientasi pada target menyebabkan guru hanya melihat buku sebagai sumber pembelajaran. Sedangkan sumber lain, seperti kearifan budaya lokal, dianggap bukan merupakan sumber pembelajaran penting bagi IPS. Ada keengganan guru menjadikan masyarakat dan lingkungan sekitarnya sebagai sumber pembelajaran. Selain belum memahami makna KTSP, guru juga dihadapkan pada kesulitan dalam memadukan materi yang ada dalam struktur kurikulum dengan nilai budaya sebagai sumber belajar lain.

3. Penguasan metode lain selain ceramah masih perlu ditingkatkan. Guru belum menggunakan variasi metode dalam pengelolaan pembelajaran padahal selain akan menumbuhkan motivasi peserta didik juga memberikan kemudahan bagi mereka dalam memahami materi pelajaran. Pemilihan metode ceramah sebagai matode yang paling sering digunakan selain akan berimbas pada model pembelajaran yang berpusat pada guru juga akan menyebabkan kelas sebagai satu-satunya tempat belajar.

4. Adanya keterbatasan waktu pembelajaran. Berdasarkankurikulumyangberlaku, durasi pembelajaran IPS setiap minggu adalah 4 jam pelajaran atau $4 \times 40$ menit. Sedikitnya waktu yang dialokasikan dalam kurikulum menyebabkan guru mengalami kesulitan dalam menyelenggarakan pembelajaran di luar kelas (out door learning). Selain sulit dalam pengelolaan waktu pembelajaran, kegiatan pembelajaran di luar kelas tidak pernah dilakukan mengingat guru merasa dibebani target untuk menyelesaikan program pembelajaran tepat waktu.

5. Pemahaman guru terhadap hakikat pembelajaran IPS. Guru memandang pembelajaran IPS sebagai mata pelajaran hafalan. Akibatnya pembelajaran IPS belum sesuai dengan hakikat mata pelajaran itu sendiri. Guru belum memahami hakikat mata pelajaran yang diampunya. Hakikat pengajaran IPS adalah pengajaran interelasi aspek-aspek kehidupan manusia di masyarakat. ${ }^{11}$

Pada proses pembelajaran selama PTK berlangsung menunjukkan, meskipun pada awalnya guru mengalami kesulitan dalam implementasi nilai kearifan budaya lokal, tetapi lambat laun hambatan yang terjadi berangsur-angsur hilang. Setelah pertemuan ketiga, Guru tidak tampak gamang lagi dalam mengelola pembelajaran. Guru dapat mengusai kelas dengan baik. Demikian juga terhadap penguasaan bahan pelajaran yang harus disampaikan kepada peserta didik, guru tidak lagi melakukan menyampaikan pesan secara verbal dan satu arah. Dampak lainnya, aktivitas peserta didik mengalami perubahan signifikan setelah beberapa kali pertemuan penelitian dilakukan. Bahkan ketika pembelajaran menggunakan model out door learning, aktivitas pembelajaran lebih didomiasi peserta didik.

Ketiga, aspek peserta didik. Peserta didik seharusnya menempati posisi sentral dalam kegiatan pembelajaran atau pendidikan. Kenyataan di lapangan menunjukkan kegiatan pembelajaran khususnya pembelajaran IPS belum menjadikan peserta didik sebagai inti dari proses tersebut. Peserta didik selalu ditempatkan pada posisi yang lebih rendah dari guru sebagai figur sentral pembelajaran yaitu sebagai penerima pesan. Hal inilah yang menyebabkan peserta didik tidak memiliki motivasi yang tinggi dalam mengikuti pembelajaran. Selain itu, kemampuan berpikir logis, kritis, dan kreatif tidak berkembang dengan baik. Hal ini terlihat jelas pada tahap orientasi penelitian tindakan dan pembelajaran siklus pertama.

Masih mengenai masalah tersebut, peserta didik tidak dibiasakan menghadapi berbagai pengalaman belajar sehingga ketika guru mencoba menerapkan model pembelajaran yang dianggap baru terjadilah kesulitan mengikutinya. Peserta didik telah terbiasa menerima informasi (penerima pesan), maka ketika harus mencari dan menemukan informasi sendiri, mereka mengalami kesulitan melakukannya. Padahal

11 Nursid Sumaatmadja. 1984. Metodologi Pengajaran Ilmu Pengetabuan Sosial. Bandung: Alumni. h. 22. 
pengetahuan itu seharusnya ditemukan dan dibangun oleh peserta didik sendiri (konstruktivistik). Demikian pula ketika peserta didik dihadapkan pada sumber belajar lain selain buku, mereka merasa bahwa sumber tersebut tidak ada hubungannya dengan materi yang ada dalam buku.

Meskipun demikian, kesulitan yang dihadapi peserta didik perlahan-lahan berkurang ketika gurumulaimembiasakandiridan peserta didiknya menjalani kegiatan pembelajaran dengan beragam pendekatan dan metode pembelajaran. Peserta didik juga mulai diperkenalkan dengan berbagai sumber pembelajaran termasuk nilai kearifan lingkungan masyarakat adat Kuta. Dengan demikian, hambatan yang dialami peserta didik sesungguhnya merupakan dampak dari kebiasaan lama guru dalam mengelola pembelajaran.

\section{Penutup}

Kampung Kuta memiliki berbagai nilai yang dapat dijadikan sumber pembelajaran IPS. Nilai tersebut terdiri nilai historis, sosial, ekonomi dan lingkungan. Nilai historis meliputi keteladanan, keberanian, tanggung jawab, dan rela berkorban. Nilai sosial meliputi solidaritas, kerja sama, gotong royong, kebersamaan dan sopan-santun. Nilai ekonomi meliputi kemandirian, kesederhanaan, produktivitas dan efisiensi. Nilai lingkungan antara lain keberlanjutan dan keseimbangan.

Kearifan budaya lokal merupakan inti dari kebudayaan yang dikembangkan oleh masyarakat adat Kuta dengan menjadikan hutan keramat yang bernama Leuweung Gede sebagai simbol keberlangsungan kebudayaan mereka. Lestarinya hutan ini merupakan bukti yang menunjukkan budaya masyarakat Kuta tetap berkembang di tengah perubahan zaman dewasa ini.

Nilai budaya masyarakat Kuta ternyata sangat bermanfaat dalam menjadikan pembelajaran IPS semakin bermakna. Hal ini terlihat dari hasil PTK yang menunjukkan berbagai perkembangan. Peserta didik lebih termotivasi karena dihadapkan pada hal baru yaitu nilai budaya sebagai sumber pembelajaran. Motivasi ini semakin meningkat ketika guru menggunakan model out door learning. Meskipun demikian, banyak hal yang harus tetap ditingkatkan sebab menurut hasil checking pasca penelitian tindakan, ternyata guru kembali ke tradisi lama dalam mengelola pembelajaran

\section{Daftar Pustaka}

Alma, Buchari. 2010. Pembelajaran Studi Sosial. Bandung: Alfabeta.

Atmodjo, M.M.S.K. 1986.” Pengertian Kearifan Lokal dan Relevansinya dalam Modernisasi" dalam Ayatrohaedi penyunting. 1986. Kepribadian Budaya Bangsa (Local Genius). Jakarta: Dunia Pustaka Jaya.

Capra, Fritjof. 2009. The Hiden Connections: Strategi Sistematik. Melawan Kapitalisme Baru (penerjemah: Andia Primanda, dari The Hidden Connection: A Science for Sustainable Living). Yogyakarta: Jalasutra .

Capra, Fritjof. 2009. Titik Balik Peradaban: Sains, Masyarakat, dan Kebangkitan Kebudayaan (penerjemah: M. Thoyibi., dari The Turning Point: Science, Society and The Rising Culture). Yogyakarta: Jejak.

Elmubarok, Zaim. 2008. Membumikan Pendidikan

Nilai. Bandung: Alfabeta.

Susilo, D. Rahmat K. 2009. Sosiologi Lingkungan. Jakarta: Rajawali Press.

Kluchohn, C. 1951. The Study of Culture. New York: Stamford University Press.

Koentjaraningrat. 1989. Pengantar Ilmu Antropologi. Jakarta: Aksara Baru.

Mutakin, Awan. 2000. Individu, Masyarakat dan Perubahan. Bandung: FPIPS UPI.

Naisbitt, J. 1994. Golbal Paradox (penterjeman: Budijanto). Jakarta: Binarupa Aksara.

Pasya, Gurniwan Kamil. 1999. Kapita Selekta Sosiologi dan Antropologi. Bandung: Buana Nusa.

Saini. K. M. 2004. Krisis Kebudayaan (Pilihan 10 essai). Bandung: Kelir.

Somantri, Muhammad Numan. 2001. Menggagas Pendidikan Pembaharuan Pendidikan IPS. Bandung: PT. Remaja Rosdakarya.

Sumaatmadja, Nursid. 1984. Metodologi Pengajaran Ilmu Pengetahuan Sosial. Bandung: Alumni.

Sumaatmajda, Nursid. 2005. Manusia Dalam Konteks Sosial, Budaya dan Lingkungan Hidup. Bandung: Alfabeta. 
Wahab, Abdul Azis. 2008. Metode dan ModelModel Mengajar Ilmu Pengetahuan Sosial. Bandung: Alfabeta. 